\title{
EROSION RATES IN THE SOUTHERN OREGON COAST RANGE: EVIDENCE FOR AN EQUILIBRIUM BETWEEN HILLSLOPE EROSION AND SEDIMENT YIELD
}

\author{
STEVEN L. RENEAU \\ Earth and Environmental Sciences Division, Mail Stop D462, Los Alamos National Laboratory, Los Alamos, NM 87545, U.S.A. \\ AND \\ WILLIAM E. DIETRICH \\ Department of Geology and Geophysics, University of California, Berkeley, CA 94720, U.S.A.
}

Received 16 July 1990

Revised 22 December 1990

\begin{abstract}
The relationship of hillslope erosion rates and sediment yield is often poorly defined because of short periods of measurement and inherent spatial and temporal variability in erosion processes. In landscapes containing hillslopes crenulated by alternating topographic noses and hollows, estimates of local hillslope erosion rates averaged over long time periods can be obtained by analysing colluvial deposits in the hollows. Hollows act as local traps for a portion of the colluvium transported down hillslopes, and erosion rates can be calculated using the age and size of the deposits and the size of the contributing source area. Analysis of colluvial deposits in nine Oregon Coast Range hollows has yielded average colluvial transport rates into the hollows of about $35 \mathrm{~cm}^{3} \mathrm{~cm}^{-1} \mathrm{yr}^{-1}$ and average bedrock lowering rates of about $0.07 \mathrm{~mm} \mathrm{yr}^{-1}$ for the last 4000 to $15000 \mathrm{yr}$. These rates are consistent with maximum bedrock exfoliation rates of about $0.09 \mathrm{~mm} \mathrm{yr}^{-1}$ calculated from six of the hollows, supporting the interpretation that exfoliation rates limit erosion rates on these slopes. Sediment yield measurements from nine Coast Range streams provide similar basin-wide denudation rates of between 0.05 and $0.08 \mathrm{~mm} \mathrm{yr}^{-1}$, suggesting an approximate steady-state between sediment production on hillslopes and sediment yield. In addition, modern sediment yields are similar in basins varying in size from 1 to $1500 \mathrm{~km}^{2}$, suggesting that erosion rates are spatially uniform and providing additional evidence for an approximate equilibrium in the landscape.
\end{abstract}

KEY wORDS Hillslope erosion rates Sediment yield Colluvium Hollows Oregon Coast Range Equilibrium

\section{INTRODUCTION}

Considerable uncertainty exists concerning the relationship of hillslope erosion rates and sediment yield in many regions, yet this is of fundamental importance in understanding short-term landscape change and longterm landscape evolution. Under conditions of dynamic equilibrium, as proposed by Hack (1960), all parts of a landscape would be downwasting at the same rate. Erosion rates in headwater and downstream parts of a basin would be equal, streams would be incising at the same rate as hillslopes are lowering, and basin-wide relief would not change over time. In the absence of significant changes in net sediment storage, hillslope sediment production rates would be equal to sediment yield. The assumption of equilibrium conditions is useful in the construction of sediment budgets for catchments where sediment storage changes appear insignificant (Dietrich and Dunne, 1978). However, changes in climate or land use can produce major fluctuations in sediment storage that invalidate such equilibrium assumptions (e.g. Trimble, 1977; Church and Slaymaker, 1989). In addition, on a longer time scale it has been argued that conditions of steady-state 
relief are unlikely because of fluctuating uplift rates and a disparity between modern rates of orogeny and erosion (e.g. Schumm, 1963; Ahnert, 1970; Carson and Kirkby, 1972).

The purpose of this study is to calculate hillslope erosion rates in the unglaciated Oregon Coast Range, and to evaluate the relation of hillslope erosion to modern sediment yield. The hillslope erosion rates are calculated using dated colluvial deposits in hollows, utilizing a method presented by Reneau et al. (1989). Hollows accumulate colluvium for extended periods of time, and the erosion rate calculations involve determining the age and size of colluvial deposits and the size of the contributing source area. An additional measure of hillslope erosion is provided by calculations of bedrock exfoliation rates at the same sites. The hillslope erosion rates are compared with modern basin-wide erosion rates calculated from stream sediment yield data. Although significant uncertainties are present in the calculated rates, a similarity among the hillslope and basin-wide erosion rates suggests that hillslope sediment production and stream sediment yield in the Oregon Coast Range are roughly in balance, and that net changes in sediment storage are minor.

\section{STUDY AREA}

The study sites are in the coastal portion of the southern Oregon Coast Range within the Millicoma, Siuslaw, Smith, and Umpqua River basins (Figure 1). The area is underlain by a thick section of Eocene graywacke

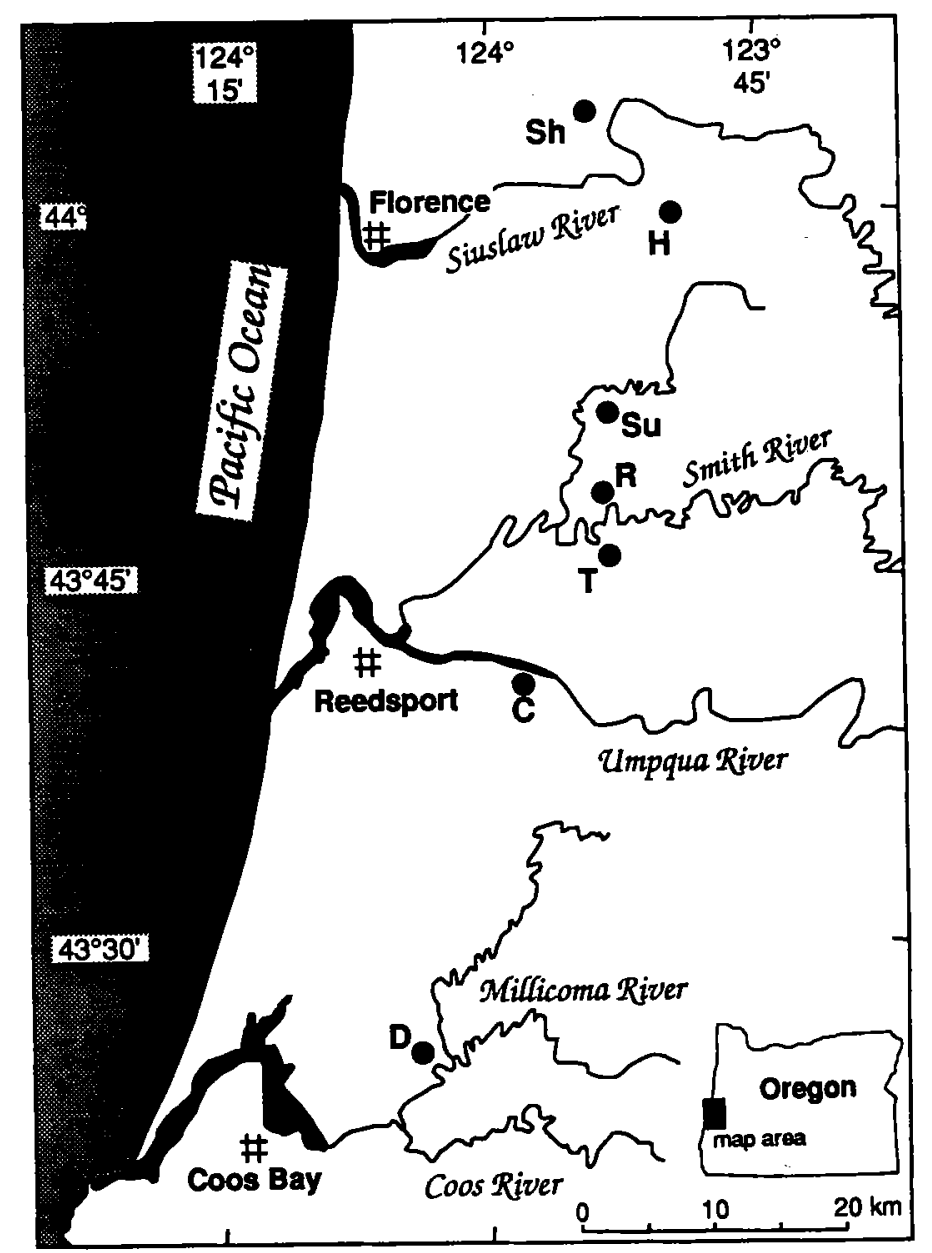

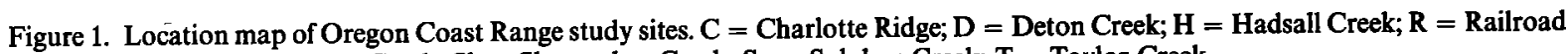
Creek; Sh = Shoemaker Creek; Su = Sulphur Creek; T = Taylor Creek 

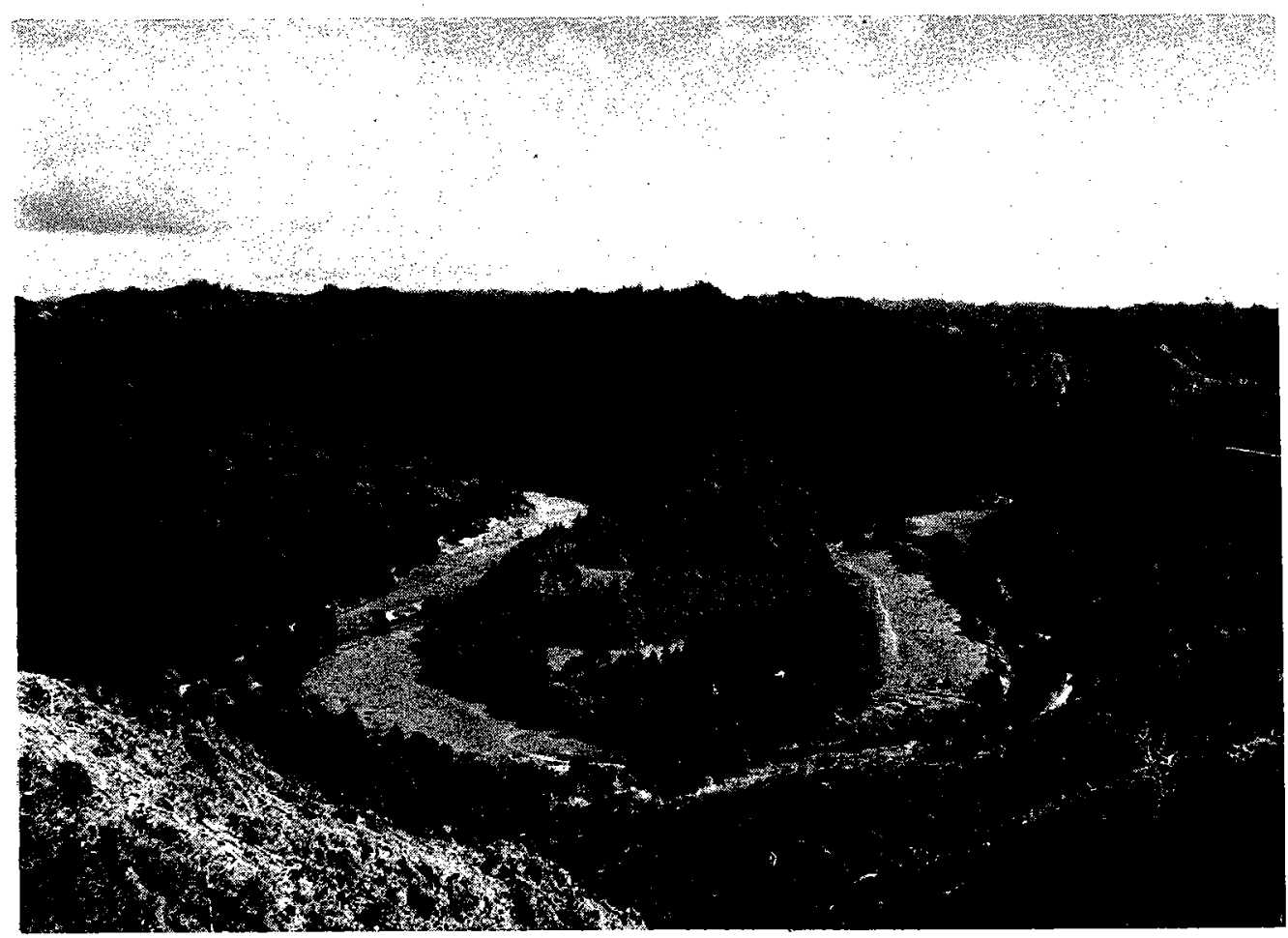

Figure 2. Photograph of meander of the Smith River at Spencer Creek. River flows from left to right, and the valley is about $350 \mathrm{~m}$ deep. This site is near the upper limit of tidewater, and the wide flat valley floor is a result of aggradation accompanying the post-glacial sea level rise. The forested area in the centre of the meander is a relict slip-off surface.

sandstone and associated shale that outcrops over a large portion of the Oregon Coast Range, mapped as part of the Tyee Formation (e.g. Snavely et al., 1964; Heller et al., 1985), or the Flournoy Formation (e.g. Baldwin and Beaulieu, 1973; Baldwin, 1974); the strata typically have gentle dips and are little deformed. Ubiquitous ingrown bedrock meanders occur along the rivers and their major tributaries (Figure 2), with relict slip-off surfaces sometimes extending through the complete depth of the valleys, suggesting a relatively continuous history of meander development accompanying incision.

Average annual rainfall at the study sites is about 2100-2500 $\mathrm{mm} \mathrm{yr}^{-1}$ (Badura et al., 1974; Pierson, 1977), and the natural vegetation is a dense coniferous forest dominated by Douglas fir (Pseudotsuga menziesii) and western hemlock (Tsuga heterophylla) (Franklin and Dyrness, 1972). Late Quaternary vegetation and climatic changes in the Oregon Coast Range are poorly known due to the absence of long palaeoenvironmental records (Heusser, 1983). The full-glacial climate in the study area was probably intermediate between relatively harsh, colder, and drier conditions near the southern end of the continental ice sheets in western and south-central Washington, 300-400 km north (e.g. Heusser, 1983, 1985; Barnosky, 1985), and relatively mild, cooler, and moister conditions in central coastal California $500-800 \mathrm{~km}$ south (e.g. Johnson, 1977; Adam et al., 1981a, 1981b). There is no evidence of glaciation or periglacial processes having occurred in this area and coniferous forests may have been maintained through the late Quaternary in coastal Oregon, although this remains speculative until palaeoenvironmental data are obtained from this region.

Clearcut logging operations are widespread in the study area and have exposed a topography dominated by alternating hollows and noses that are typically spaced about 30-40 m apart (Figure 3), similar to the 'ridge and ravine topography' of Hack (1960). As defined by Hack and Goodlett (1960), hollows are the parts of hillslopes with contours concave-out from the ridge, noses are the areas with convex-out contours, and side slopes are the intervening areas with straight contours. In the study area, soils are generally thin on the noses and side slopes, about $0.5 \mathrm{~m}$ thick or less, and much thicker in hollows. Colluvial deposits in the 


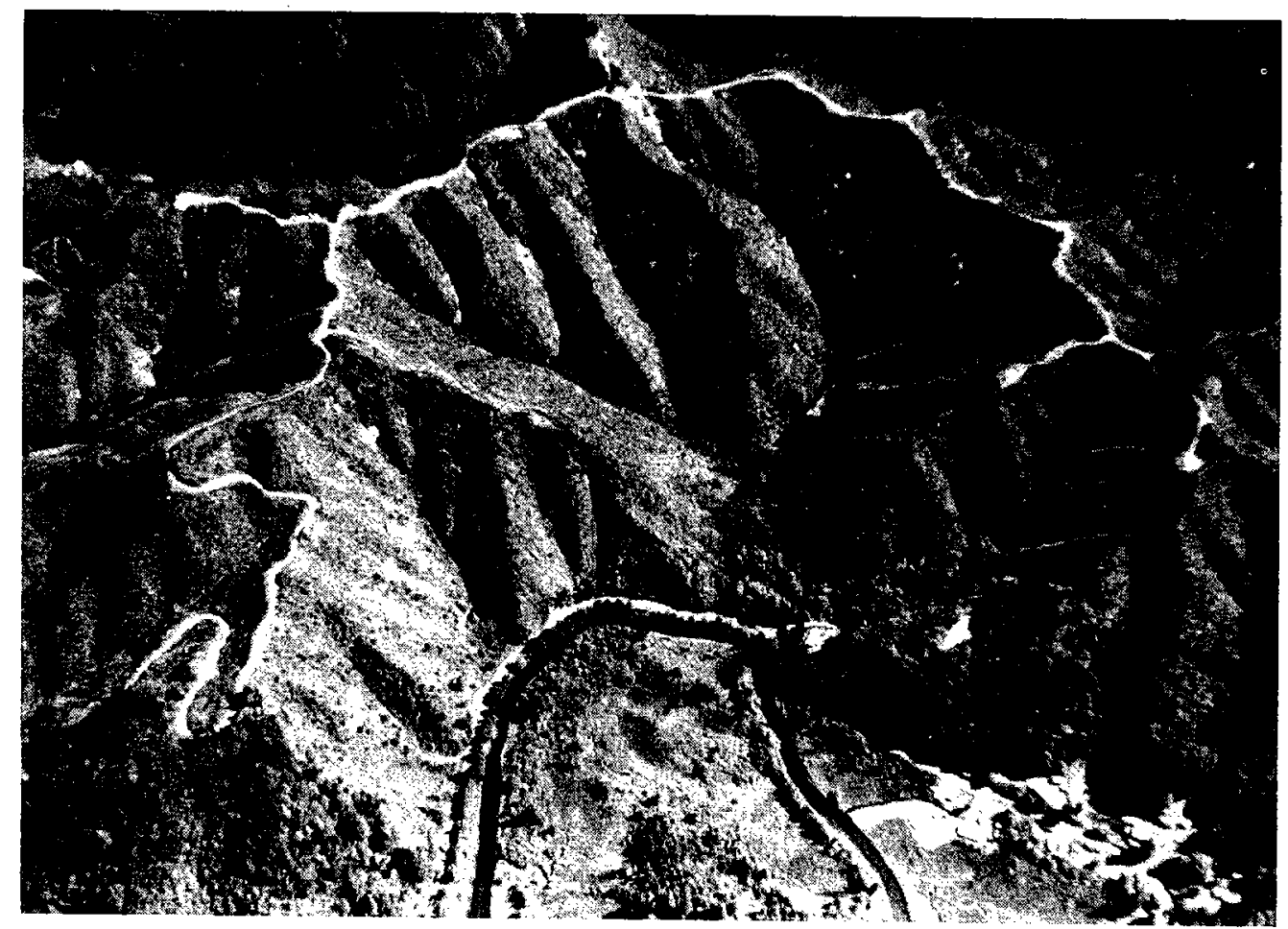

Figure 3. Oblique aerial photograph of clearcut slopes in the Millicoma River basin, underlain by Eocene sandstones of the Tyee-Flournoy Formation. The hillslopes are dominated by a series of alternating topographic hollows and noses

hollows are the primary source of debris flows in this area (Pierson, 1977; Swanson et al., 1981; Benda and Dunne, 1987; Benda, 1990b), episodically discharging the stored colluvium to stream channels.

On hillslopes in the study area underlain by massive sandstone, exfoliation sheets develop roughly parallel to the ground surface (Figure 4). Observations of fresh roadcut exposures indicate that beneath the thin soils on side slopes and noses, tree roots penetrate and break up the exfoliation sheets as they develop. In contrast, multiple exfoliation sheets are present beneath hollows where soils are thicker and roots rarely penetrate into the bedrock, with these exfoliation sheets only being broken up and removed after the colluvium is stripped from a hollow. These observations suggest that the rate of exfoliation limits the hillslope sediment production rate in the study area, and that erosion rate on the noses and side slopes are thus weathering-limited or detachment-limited, rather than transport-limited as commonly assumed for soil-mantled hillslopes (e.g. Carson and Kirkby, 1972, pp. 104-105). In addition, upstream of Holocene fills near the coast, large streams in the Oregon Coast Range typically expose bedrock on their beds and have little alluvium in storage (e.g. Benda and Dunne, 1987; Grabau, 1990), suggesting that sediment yield from the basins is controlled by the sediment discharge rate from hillslopes, although sediment yield from low-order basins may be strongly episodic and related to debris flow occurrence (Benda, 1990b).

\section{Sediment yield}

Sediment yield data are available for nine Oregon Coast Range streams, with the drainage basins ranging from about 1 to $1500 \mathrm{~km}^{2}$ in area (Table I). Although logging is widespread in the region, and most of the sediment yield data are affected by upstream logging and road construction, the available data from both large and small basins are relatively consistent, and measurements from several small undisturbed basins allow a comparison with the partially logged basins.

The only data from undisturbed basins were presented by Brown and Krygier (1971) and Beschta (1978), who reported 15 years of suspended sediment data from three small watersheds within the Alsea River basin, 

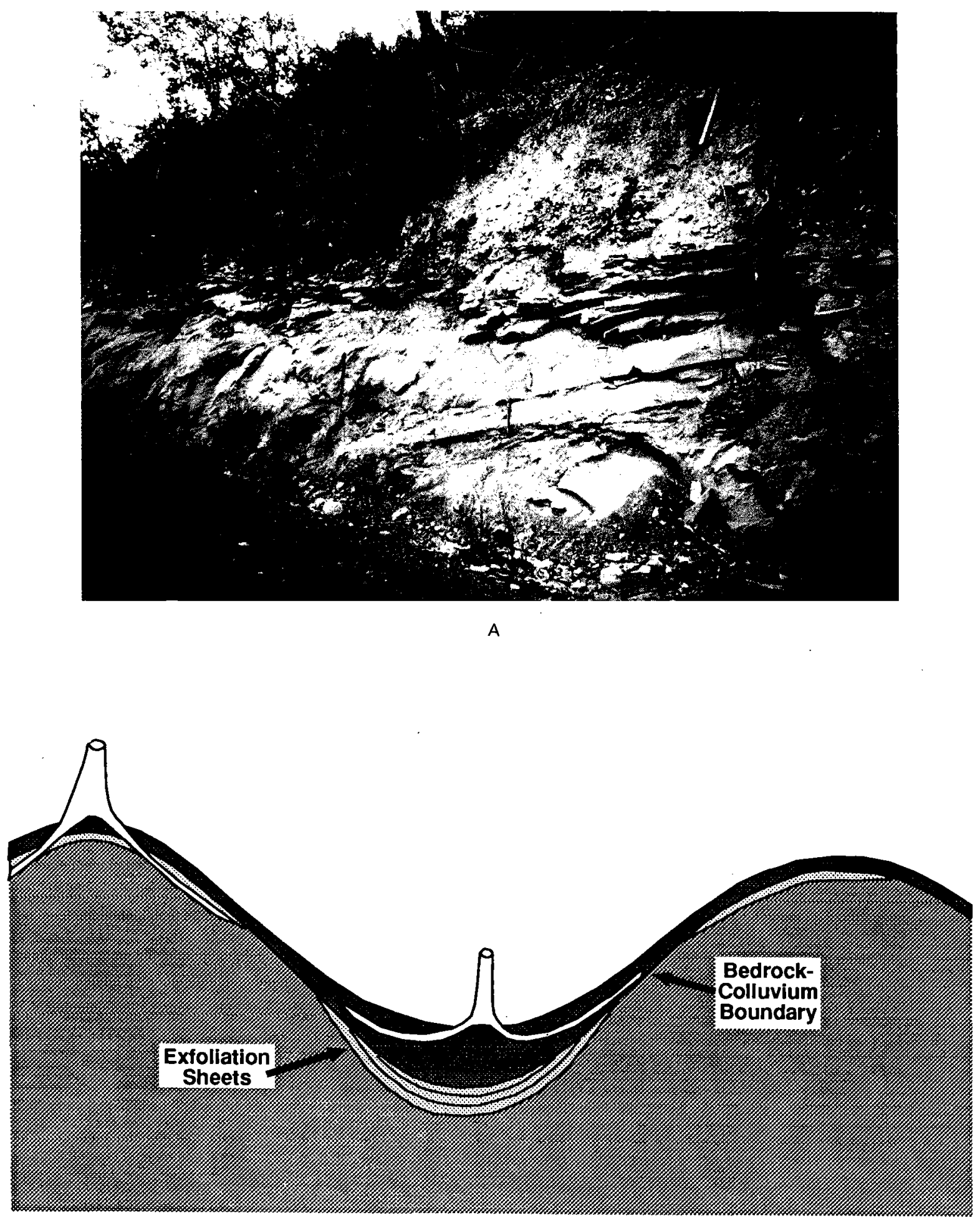

B

Figure 4. (A) Photograph of exfoliation sheets developed on Tyee Formation sandstone at edge of Hadsall Creek colluvial deposit. (B) Sketch showing distribution of exfoliation sheets in relation to soil thickness. Roots penetrate and break up the sheets beneath thin soils on side slopes and noses, whereas multiple sheets are present beneath thick colluvial deposits in hollows 
Table I. Sediment yield data from the Oregon Coast Range

\begin{tabular}{|c|c|c|c|c|}
\hline Site & $\begin{array}{c}\text { Drainage } \\
\text { area } \\
\left(\mathrm{km}^{2}\right)\end{array}$ & $\begin{array}{l}\text { Type of } \\
\text { measurement }\end{array}$ & $\begin{array}{l}\text { Length of } \\
\text { record } \\
\text { (years) }\end{array}$ & $\begin{array}{c}\text { Average } \\
\text { sediment yield } \\
\left(\mathrm{t} \mathrm{km}^{-2} \mathrm{yr}^{-1}\right)\end{array}$ \\
\hline \multicolumn{5}{|l|}{ Alsea River Basin ${ }^{2}$} \\
\hline \multirow[t]{2}{*}{ Needle Branch } & \multirow[t]{2}{*}{$0 \cdot 7$} & \multirow[t]{2}{*}{ SS } & 7 & $53^{6}$ \\
\hline & & & 8 & 146 \\
\hline Flynn Creek & $2 \cdot 0$ & SS & 15 & $98^{6}$ \\
\hline \multirow[t]{2}{*}{ Deer Creek } & \multirow[t]{2}{*}{$3 \cdot 0$} & \multirow[t]{2}{*}{ SS } & 7 & $97^{6}$ \\
\hline & & & 8 & 157 \\
\hline \multicolumn{3}{|c|}{ All Alsea measurements from undisturbed basins } & 29 & 87 \\
\hline All Alsea measur & rom disturb & basins & 16 & 141 \\
\hline \multicolumn{5}{|c|}{ Umpqua River Basin } \\
\hline Cooper Creek ${ }^{3}$ & $11 \cdot 4$ & RS & 11 & 179 \\
\hline Sutherlin Creek $^{3}$ & $23 \cdot 3$ & RS & 11 & 174 \\
\hline Olalla Creek ${ }^{4}$ & 158 & SS & 18 & 95 \\
\hline Yaquina River 5 & 655 & SS & 2 & 129 \\
\hline Alsea River ${ }^{5}$ & 865 & SS & 2 & 187 \\
\hline Siuslaw River ${ }^{5}$ & 1,523 & SS & 7 & 125 \\
\hline
\end{tabular}

${ }^{1} \mathrm{RS}=$ reservoir sedimentation; SS = suspended sediment

${ }^{2}$ From Brown and Krygier (1971) and Beschta (1978). Bedrock is sandstone of Tyee Formation. Mean annual precipitation is about $2500 \mathrm{~mm} \mathrm{yr}^{-1}$.

${ }^{3}$ From Larson and Sidle (1980). Bedrock is sandstone, siltstone, and shale of Umpqua Formation. Mean annual precipitation is about $1000 \mathrm{~mm} \mathrm{yr}^{-1}$.

${ }^{4}$ From Larson and Sidle (1980). Bedrock is marine sedimentary rocks. Mean annual precipitation is about $1100 \mathrm{~mm} \mathrm{yr}^{-1}$.

${ }^{5}$ From Karlin (1980). Bedrock is mainly sandstone of Tyee Formation.

${ }^{6}$ Unlogged basin.

including measurements before and after logging in two of these. Bedrock at the Alsea sites is sandstone of the Tyee Formation, and is thus similar to bedrock at the dated colluvial deposits in this study. The average suspended sediment yield from all years of record in the disturbed Alsea basins in $141 \mathrm{t} \mathrm{km}^{-2} \mathrm{yr}^{-1}$, while the average of all measurements from the unlogged basins is $87 . \mathrm{km}^{-2} \mathrm{yr}^{-1}$ (Table I). Using an average unweathered bedrock density of $2.27 \mathrm{tm}^{-3}$ (discussed in a subsequent section) and average chemical denudation rates for this area of about $25-30 \mathrm{t} \mathrm{km}^{-2} \mathrm{yr}^{-1}$ (Dethier, 1986), the sediment yield from the undisturbed basins is equivalent to a bedrock lowering rate of about $0.05 \mathrm{~mm} \mathrm{yr}^{-1}$.

Additional sediment yield data are available from six larger, partially disturbed basins in the Oregon Coast Range underlain by sedimentary bedrock. Karlin (1980) reported sediment yields of $125-187 \mathrm{t} \mathrm{km}^{-2} \mathrm{yr}^{-1}$ from 2-7 years of suspended sediment data for the much larger Alsea, Siuslaw, and Yaquina River basins (Table I), underlain primarily by Tyee-Flournoy strata. The highest yield of $187 \mathrm{t} \mathrm{km}^{-2} \mathrm{yr}^{-1}$, for the Alsea River basin, was based on only two years of measurement and may not be representative. Eighteen years of suspended sediment measurements for Olalla Creek in the Umpqua River basin, including the major storm of January 1964, yield an average of $95 \mathrm{t} \mathrm{km}^{-2} \mathrm{yr}^{-1}$ (Table I). Additional sediment measurements are available from two reservoirs in the Umpqua River basin, providing almost identical sediment yields of 174 and $179 \mathrm{t} \mathrm{km}^{-2} \mathrm{yr}^{-1}$ (Table I).

The suspended sediment yield data underestimate total particulate yield by neglecting bedload transport, although this is probably of minor importance in calculating erosion rates in this region. For example, three years of partial bedload data from Flynn Creek in the Alsea River basin (Larson and Sidle, 1980) indicate that bedload is on the order of only 3 per cent of total sediment yield. In addition, data from three rivers in western Washington, summarized in Collins and Dunne (1989), suggest that bedload is typically about 4 per cent of suspended load. Uncertainties in including bedload are well within the error of estimating the suspended sediment yield, as well as within the variability in measurements between basins, and inclusion of bedload would probably not change significantly the values in Table I. 
Based on the above data, average total sediment yield for undisturbed basins in the Oregon Coast Range is probably well below a maximum value of about $190 \mathrm{t} \mathrm{km}^{-2} \mathrm{yr}^{-1}$ obtained from disturbed basins, and may be as low as about $85 \mathrm{t} \mathrm{km}^{-2} \mathrm{yr}^{-1}$. The data from undisturbed basins may be too low as they do not include the brief periods of high sediment yield associated with major fires (e.g. Swanson, 1981; Benda, 1990a), thus providing a lower limit for denudation rates of about $0.05 \mathrm{~mm} \mathrm{yr}^{-1}$. An upper limit is perhaps provided by the average of values from disturbed basins of $149 \pm 31 \mathrm{t} \mathrm{km}^{-2} \mathrm{yr}^{-1}$, equivalent to an average denudation rate of about $0.08 \mathrm{~mm} \mathrm{yr}^{-1}$.

\section{EVALUATION OF HILLSLOPE EROSION RATES}

\section{Procedure}

Hillslope erosion rates in this study were calculated from dated colluvial deposits using equations derived in Reneau et al. (1989). Briefly, this method assumes that a definable portion of the colluvium transported down hillslopes is trapped in hollows. If colluvial transport rates down the axis of a hollow are dependent on the slope gradient, and are constant in the part being evaluated, then net deposition is entirely due to the added colluvium transported into the hollow from the adjacent side slopes. The mass of colluvium deposited per unit length of hollow axis, $M_{l h}$, between two stratigraphic levels $z_{2}$ and $z_{3}$, is calculated by combining data on colluvial density with measurements of the cross-sectional size of the deposit in the following equation:

$$
M_{l h}=\int_{z_{2}}^{z_{3}} w_{z} \rho_{z} \mathrm{~d} z
$$

where $w_{z}$ is deposit width as a function of depth, $z$, and $\rho_{z}$ is density of the colluvium as a function of depth. For the calculations used in this paper, $z_{3}$ is the present ground surface. The age of the deposit is determined from radiocarbon dating of charcoal contained within the colluvium, and is used to calculate average mass depositional rates of colluvium, $\mathrm{d} M_{l h} / \mathrm{d} t$. Using measurements of the width of the contributing basin, $w_{b}$, and the density of weathered bedrock, $\rho_{b}$, the accumulated colluvium is spread over the adjacent hillslopes and an equivalent average bedrock lowering rate, $\mathrm{d} z_{b} / \mathrm{d} t$, is calculated:

$$
\frac{\mathrm{d} z_{b}}{\mathrm{~d} t}=\frac{1}{\rho_{b}\left(w_{b}-w_{\mathrm{d}}\right)} \frac{\mathrm{d} M_{l h}}{\mathrm{~d} t}
$$

where $w_{d}$ is average deposit width. This bedrock lowering rate can also be expressed as an equivalent sediment production rate, $Q_{s}$, equal to a long-term sediment yield if net storage changes in a basin are negligible:

$$
Q_{s}=\rho_{b} \frac{\mathrm{d} z_{b}}{\mathrm{~d} t}
$$

Calculations of volumetric colluvial transport rates, $q_{v}$, into each hollow were made using measurements of local topographic convergence, given by a convergence angle, $\beta$, average soil density, $\rho_{s}$, and the mass depositional rate of colluvium:

$$
q_{v}=\frac{1}{2 \rho_{s} \sin \beta} \frac{\mathrm{d} M_{l h}}{\mathrm{~d} t}
$$

The convergence angle, $\beta$, is measured as the angle between the orientation of the hollow axis and the orientation of the adjacent side slopes, with $\beta$ equal to zero where contours are straight and there is no topographic convergence. This method of calculating colluvial transport rates differs from that used by Benda and Dunne (1987) and Benda (1990b) for similar sites in the Oregon Coast Range, as their method assumes transport perpendicular to the hollow axis; use of a convergence angle to account for colluvial transport oblique to hollow axes yields higher calculated transport rates. Estimates of average residence times of colluvium on the side slopes can also be made by dividing the volume of colluvium stored on the side slopes by the colluvial transport rate into the hollows (Dietrich and Dunne, 1978). In the above calculations, 
possible measurement uncertainties of about \pm 25 per cent are estimated from uncertainties in density, crosssectional area, and basin geometry (Reneau et al., 1989).

Calculations of apparent exfoliation rates were also made at the same locations by dividing the thickness of the sheeted zone beneath each hollow, as measured in roadcuts, by the age of the colluvial deposit. These calculated exfoliation rates would be too high if all older exfoliation sheets were not removed prior to deposition of the basal colluvium. It was not possible to determine in the field if such inherited exfoliation sheets were present, and so the rates calculated by this method should be considered maximum-limiting estimates of exfoliation rates.

Radiocarbon ages differ from true calendar ages, and the use of uncalibrated radiocarbon ages would introduce additional error into the calculation of erosion rates. In this study, the computer program of Stuiver and Reimer (1986) was used to obtain calibrated radiocarbon ages for samples with ages of about $8000 \mathrm{yr}$ B.P. and younger, and approximate corrections were used for older samples based on the preliminary calibrations of Stuiver et al. (1986) to about $12000 \mathrm{yr}$ B.P.

Dissolution of colluvium on the side slopes and in the hollows causes a mass loss and, as a result, the above method underestimates actual bedrock lowering rates. In addition, the calculated colluvial transport rates are also underestimated, by a lesser amount, because of the dissolution of colluvium in the hollow. Approximate corrections can be made for these effects using data on total chemical denudation in an area and data on the densities of fresh and weathered bedrock (Reneau et al., 1989).

\section{Study sites}

Nine colluvial deposits in hollows were selected for study. Site selection was based on the presence of adequate roadcut exposures of colluvial deposits, the availability of charcoal for dating, and the ability to characterize the basin geometry; the topography at the sampled hollows is similar to that developed throughout the extensive outcrop area of Eocene sandstone in the Oregon Coast Range. Hollows with thin soils $(<1 \mathrm{~m})$ were avoided because of the difficulty of defining deposit width at these sites and so that a longer record could be obtained. The roadcut exposures range from 15 to $130 \mathrm{~m}$ below ridgecrests, with upslope drainage areas ranging from about 100 to $4000 \mathrm{~m}^{2}$; most sites are within $50 \mathrm{~m}$ of the ridgecrest, with drainage areas of $1500 \mathrm{~m}^{2}$ or less (Table II). Axial gradients of the hollows range from $28-37^{\circ}$ at the roadcut exposures, and adjacent side slope gradients range from $29-40^{\circ}$. Texturally, the colluvium at all sites is a loam, containing varying proportions of matrix-supported gravel clasts derived from the Eocene sandstone. Most of the studied deposits have brownish colours, with Munsell hues of 10 YR, although reddish (Munsell hue 5 YR), clay-rich colluvium in the lower horizon of one dated deposit (Railroad Creek \#2) suggests significantly greater age (Reneau, 1988).

\section{Radiocarbon dates}

Twenty-five radiocarbon dates were obtained from charcoal contained within the nine colluvial deposits, including multiple stratigraphic levels in six of these (Table III). The charcoal generally occurred as disseminated fragments in diffuse layers roughly parallel to the ground surface, although isolated fragments were also sampled. Burnt roots were seen in many deposits, and the downward transport of relatively young charcoal in animal burrows or root holes was evident in some deposits; these occurrences of charcoal were avoided.

Basal ages of the colluvial deposits range from $4 \mathrm{ka}$ to greater than $40 \mathrm{ka}$. Most of the deposits are Holocene in age, and seven of the nine sites yielded basal ages between 4 and $7.5 \mathrm{ka}$ (Table III). At Railroad Creek \#2, a $>40 \mathrm{ka}$ date obtained from the lower horizon confirmed its significantly older age; three additional dates higher in the section document continued thickening through the latest Pleistocene and the Holocene. The dates from multiple stratigraphic levels at five other sites also document that the deposits are cumulative. For example, five dates from the Hadsall Creek deposit (Figure 5) and four dates from Taylor Creek document progressive thickening from about 4-5 ka until present (Reneau, 1988; Reneau and Dietrich, 1990).

With only one exception, all of the dates from multiple stratigraphic levels are stratigraphically consistent within the laboratory uncertainty, being younger upward in the section. The exception is at Deton Creek 


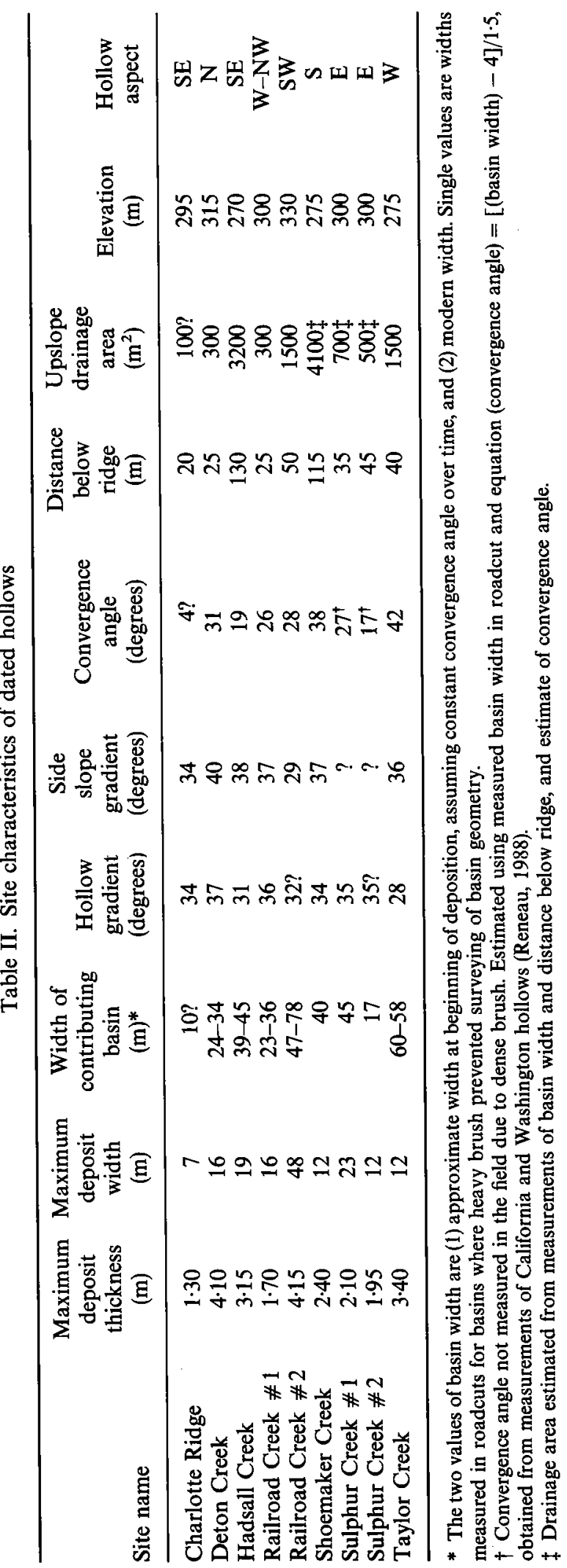


Table III. Radiocarbon dates

\begin{tabular}{lcrl}
\hline Site name & $\begin{array}{c}\text { Depth } \\
(\mathrm{m})\end{array}$ & \multicolumn{1}{c}{$\begin{array}{c}\text { Age } \\
\text { (yr B.P.) }\end{array}$} & $\begin{array}{c}\text { Laboratory } \\
\text { number }\end{array}$ \\
\hline Charlotte Ridge & $1 \cdot 30$ & $4660 \pm 110$ & Beta-20964 \\
Deton Creek & $0 \cdot 45$ & $820 \pm 50$ & AA-2541 \\
& $0 \cdot 95$ & $5710 \pm 200$ & W-5890 \\
& $1 \cdot 70$ & $4400 \pm 200$ & W-5891 \\
Hadsall Creek & $3 \cdot 90$ & $10500 \pm 500$ & W-5889 \\
& $0 \cdot 25$ & $<200$ & W-5907 \\
& $0 \cdot 75$ & $1570 \pm 150$ & W-5892 \\
& $1 \cdot 05$ & $3390 \pm 300$ & W-5898 \\
& $1 \cdot 65$ & $4215 \pm 250$ & W-5895 \\
Railroad Creek \#1 & $2 \cdot 85$ & $4140 \pm 110$ & Beta-20967 \\
& $0 \cdot 50$ & $2500 \pm 140$ & Beta-26505 \\
Railroad Creek \#2 & $1 \cdot 10$ & $7400 \pm 140$ & Beta-20965 \\
& $0 \cdot 25$ & $2160 \pm 60$ & AA-2553 \\
& $0 \cdot 80$ & $5030 \pm 90$ & AA-2551 \\
Shoemaker Creek & $1 \cdot 50$ & $14810 \pm 140$ & AA-2552 \\
& $2 \cdot 30$ & $>40000$ & AA-2554 \\
Sulphur Creek \#1 & $0 \cdot 45$ & $1010 \pm 120$ & Beta-26507 \\
Sulphur Creek \#2 & $0 \cdot 85$ & $1235 \pm 75$ & Beta-26814 \\
Taylor Creek & $1 \cdot 40$ & $6940 \pm 200$ & W-5902 \\
& $1 \cdot 95$ & $7260 \pm 80$ & AA-2555 \\
& $0 \cdot 35$ & $380 \pm 60$ & Beta-20966 \\
& $0 \cdot 90$ & $1410 \pm 50$ & AA-2557 \\
& $1 \cdot 70$ & $3500 \pm 80$ & AA-2556 \\
& $2 \cdot 55$ & $4570 \pm 190$ & W-5908 \\
\hline
\end{tabular}
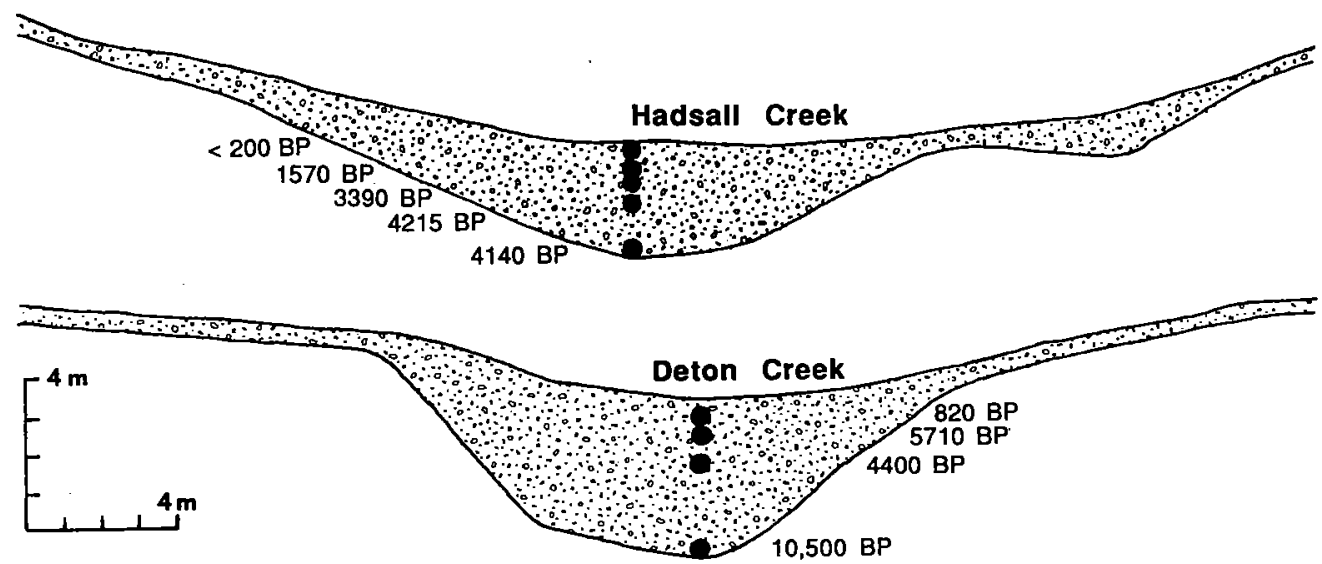

Figure 5. Cross-sections across the Deton Creek and Hadsall Creek colluvial deposits, showing locations of dated charcoal samples

where a $5710 \mathrm{yr}$ B.P. date from a depth of $0.95 \mathrm{~m}$ conflicts with a $4410 \mathrm{yr}$ B.P. date from $1.70 \mathrm{~m}$ (Figure 5). This stratigraphic inconsistency may record bioturbation of the section; the dating of burnt roots instead of detrital charcoal; or possibly the downward transport of relatively young charcoal in animal burrows. The general consistency of dates from deposits with multiple dated levels, however, suggests that most of the dates 
are accurate and that it was usually possible to distinguish charcoal deposited contemporaneously with the colluvium from younger charcoal.

\section{Density measurements}

Colluvium from multiple stratigraphic levels at four of the dated deposits was sampled for bulk density determinations, consisting of 53 samples of known volume collected with a hand-held corer and nine undisturbed bulk samples analysed as a comparison. The samples show a progressive increase in dry bulk density with depth, from about $0.8 \mathrm{t} \mathrm{m}^{-3}$ near the surface to about $1.5 \mathrm{t} \mathrm{m}^{-3}$ at depths of 2-3 $\mathrm{m}$ (Figure 6). Procedures used in the bulk density analyses are discussed further in Reneau et al. (1989) pertaining to colluvial deposits in Washington, including the limitations of samples collected by both methods. Core samples from the lower colluvium in Oregon average about 6 per cent less dense than bulk samples at the same depth, as also seen for colluvium in Washington (Reneau et al., 1989), and probably reflects an undersampling of gravel. Density values obtained from the core samples are therefore increased by 6 per cent to derive a relationship between bulk density and depth. The best fit through these data is provided by the following second-order polynomial equation:

$$
\rho_{z}=0.894+0.474 d-0 \cdot 106 d^{2}
$$

where $d$ is the depth below the ground surface, in $\mathrm{m}$, and $\rho_{z}$ is in units of tonnes per $\mathrm{m}^{3}$. This equation is strictly valid only to depths of about $2.7 \mathrm{~m}$, the limit of available data. Its application in this study to depths as great as $4 \mathrm{~m}$ underestimates mass in the lower horizons, although this error is of little significance in the calculation of erosion rates due to the small volume of colluvium contained within the lower horizons. From the above equation, the average density for the upper $0.5 \mathrm{~m}$, the approximate thickness of side slope soils, is about $1.0 \mathrm{tm}^{-3}$.

Bedrock samples were obtained from roadcut exposures at 13 locations beneath the study basins for density measurements. These included samples of relatively hard sandstone from depths of several metres, samples of sheeted sandstone immediately beneath the colluvium, and samples of more weathered sandstone beneath old colluvial deposits. Systematic variations in density are apparent between the three populations,

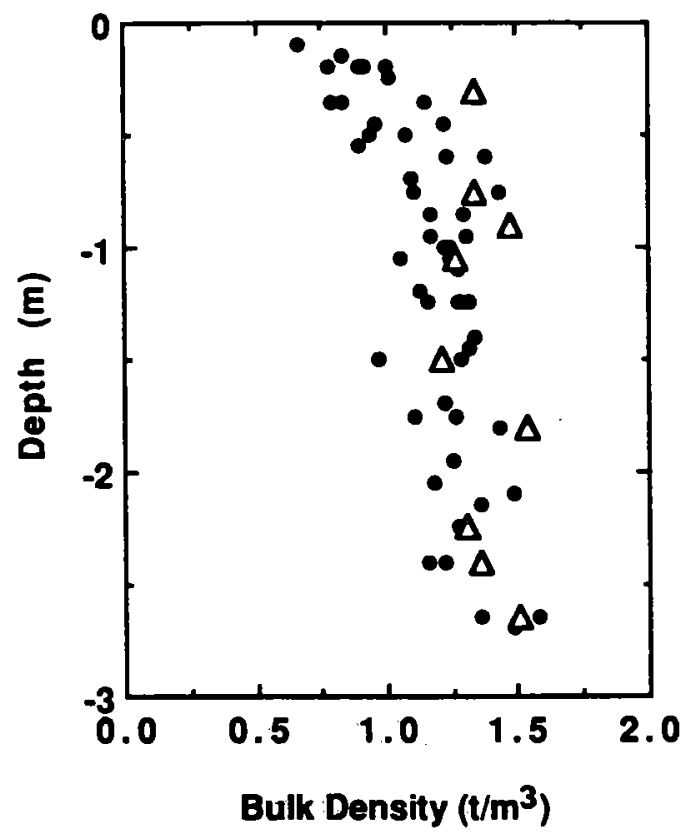

Figure 6. Plot of bulk density of colluvium versus depth for four deposits in the Oregon Coast Range; dots are core samples and triangles are bulk samples 
reflecting progressive mass loss over time during weathering. The average density of the uppermost sheeted sandstone is $2.02 \mathrm{t} \mathrm{m}^{-3}, 11$ per cent less dense than samples of deeper, unsheeted sandstone $\left(2.27 \mathrm{t} \mathrm{m}^{-3}\right)$. In contrast, samples collected from beneath relatively old colluvial deposits yield an average of $1.60 \mathrm{tm}^{-3}, 30$ per cent less dense than the deep sandstone samples (Reneau, 1988). This density change is probably due to mass loss from dissolution and not to systematic mineralogic changes, as measurements of the average grain density for samples of the most and least dense sandstone provide virtually identical values of $2.66 \pm 0.01 \mathrm{t} \mathrm{m}^{-3}$. For erosion rate calculations in this study, a value of $2.0 \mathrm{t} \mathrm{m}^{-3}$ is used for the density of
weathered bedrock.

\section{Calculated erosion rates}

Colluvial transport rates for each site, averaged over the entire period of record, range from 14 to $90 \mathrm{~cm}^{3} \mathrm{~cm}^{-1} \mathrm{yr}^{-1}$ and average about $32 \mathrm{~cm}^{3} \mathrm{~cm}^{-1} \mathrm{yr}^{-1}$ (Table IV). Equivalent bedrock lowering rates range from 0.03 to $0.11 \mathrm{~mm} \mathrm{yr}^{-1}$, averaging about $0.057 \mathrm{~mm} \mathrm{yr}^{-1}$ (Table IV). The apparent pre-15 ka rates from Railroad Creek \#2 are much lower than the post-15 ka rates, and lower than all other sites. This discrepancy may be due to the presence of a pre-15 ka unconformity in the deposit, although a clear unconformity was not observed in the field. Excluding the pre- $15 \mathrm{ka}$ record at Railroad Creek \#2 yields a slightly higher average bedrock lowering rate for all sites of $0.061 \mathrm{~mm} \mathrm{yr}^{-1}$, with a standard deviation of $0.025 \mathrm{~mm} \mathrm{yr}^{-1}$, and an average colluvial transport rate of $34 \pm 23 \mathrm{~cm}^{3} \mathrm{~cm}^{-1} \mathrm{yr}^{-1}$ (Table IV). This is equivalent to a hillslope sediment production rate of $122 \pm 50 \mathrm{t} \mathrm{km}^{-2} \mathrm{yr}^{-1}$. Calculated residence times for colluvium on the side slopes range from about 2500 to $9000 \mathrm{yr}$, averaging about 5000-6000 yr (Reneau, 1988). The variation in calculated rates between sites is significantly larger than the estimated measurement uncertainty of about 25 per cent, and probably reflects inherent spatial and temporal variability in hillslope erosional processes. No basin-size bias is seen in the data, with average rates for the smaller basins, $100-700 \mathrm{~m}^{2}$ in area; being essentially the same as rates calculated from the larger basins (Table IV). Similarly,

Table IV. Calculated average erosion rates from dated hollows*

\begin{tabular}{|c|c|c|c|}
\hline Site name & $\begin{array}{l}\text { Mass } \\
\text { depositional } \\
\text { rate } \\
\left(\mathrm{t} \mathrm{m}^{-1} \mathrm{ka}^{-1}\right)\end{array}$ & $\begin{array}{c}\text { Colluvial } \\
\text { transport } \\
\text { rate } \\
\left(\mathrm{cm}^{3} \mathrm{~cm}^{-1} \mathrm{yr}^{-1}\right)\end{array}$ & $\begin{array}{l}\text { Bedrock } \\
\text { lowering } \\
\text { rate } \\
\left(\mathrm{mm} \mathrm{yr}^{-1}\right)\end{array}$ \\
\hline $\begin{array}{l}\text { Charlotte Ridge } \\
\text { Deton Creek } \\
\text { Hadsall Creek } \\
\text { Railroad Creek \#1 } \\
\text { Railroad Creek \#2, total } † \\
\quad 0 \text {-15 ka } \\
\text { Shoemaker Creek } \\
\text { Sulphur Creek \#1 } \\
\text { Sulphur Creek \#2 } \\
\text { Taylor Creek }\end{array}$ & $\begin{array}{r}0 \cdot 6 \\
3 \cdot 2 \\
6 \cdot 7 \\
1 \cdot 4 \\
2 \cdot 1 \\
4 \cdot 5 \\
2 \cdot 2 \\
2 \cdot 8 \\
11 \cdot 3 \\
4 \cdot 3\end{array}$ & $\begin{array}{l}37 \\
36 \\
89 \\
14 \\
20 \\
38 \\
16 \\
26 \\
19 \\
27\end{array}$ & $\begin{array}{l}0.058 \\
0.081 \\
0.112 \\
0.032 \\
0.031 \\
0.063 \\
0.035 \\
0.050 \\
0.074 \\
0.042\end{array}$ \\
\hline \multicolumn{2}{|c|}{$\begin{array}{l}\text { Average of all hollows } \ddagger \\
\text { Average of all hollows, excluding pre-15 ka } \\
\text { record at Railroad Creek \#2 }\end{array}$} & $\begin{array}{l}32 \pm 23 \\
34 \pm 23\end{array}$ & $\begin{array}{l}0.057 \pm 0.027 \\
0.061 \pm 0.025\end{array}$ \\
\hline
\end{tabular}

* Rates calculated using calibrated ${ }^{14} \mathrm{C}$ dates obtained with the computer program of Stuiver and Reimer (1986) for dates of less than $8 \mathrm{ka}$, and using the preliminary calibrations of Stuiver et al. (1986) for older dates. Deposit size data and basin geometry data used in calculations
presented in Table II.

$\dagger$ Rates for the entire section at Railroad Creek \#2 are maximum values due to the infinite radiocarbon age from the lower horizon, assuming that no unconformities are present in the
section.

$\ddagger$ Plus-or-minus values are standard deviations reflecting variations in calculated rates between
the nine sites. 
Table V. Calculated exfoliation rates

\begin{tabular}{lcc}
\hline & $\begin{array}{c}\text { Thickness of } \\
\text { exfoliation } \\
\text { sheets } \\
(\mathrm{m})\end{array}$ & $\begin{array}{c}\text { Exfoliation } \\
\text { rate } \\
\left(\mathrm{mm} \mathrm{yr}^{-1}\right)^{*}\end{array}$ \\
\hline Charlo name & 0.38 & 0.071 \\
Deton Creek & 0.9 & 0.078 \\
Hadsall Creek & 0.5 & 0.105 \\
Railroad Creek \#1 & 0.8 & 0.098 \\
Sulphur Creek \#1 & $1 \cdot 0$ & 0.130 \\
Sulphur Creek \#2 & 0.5 & 0.062 \\
\hline
\end{tabular}

* Rates calculated using calibrated ${ }^{14} \mathrm{C}$ dates obtained with the computer program of Stuiver and Reimer (1986) for dates of less than $8 \mathrm{ka}$, and using the preliminary calibrations of Stuiver et al. (1986) for older dates.

the calculated erosion rates do not vary significantly with side slope gradient, although the highest rates were calculated for the two hollows with the steepest side slopes.

Average chemical denudation rates of $25-30 \mathrm{t} \mathrm{km}^{-2} \mathrm{yr}^{-1}$ have been calculated for the Siuslaw and West Fork Millicoma Rivers in the Oregon Coast Range (Dethier, 1986), and, assuming that these values are representative of the studied hillslopes, total denudation in the area is thus about $150 \pm 53 \mathrm{t} \mathrm{km}^{-2} \mathrm{yr}^{-1}$. The density measurements of weathered and unweathered sandstone indicate that roughly 11 per cent of the denudation on a typical hillslope is by dissolution of bedrock, equal to $17 \pm 6 \mathrm{t} \mathrm{km}^{-2} \mathrm{yr}^{-1}$. This analysis suggests that the remaining chemical denudation, about $10 \mathrm{t} \mathrm{km}^{-2} \mathrm{yr}^{-1}$, is by dissolution of surficial materials, and that the lowering rates calculated from the colluvial deposits are thus roughly 8 per cent too low. Using this approximate correction for dissolution increases the average bedrock lowering rate to $0.066 \pm 0.027 \mathrm{~mm} \mathrm{yr}^{-1}$. Calculated colluvial transport rates should be increased by a smaller amount, reffecting only dissolution of the colluvial deposits, and the average transport rate is thus about $36 \mathrm{~cm}^{3} \mathrm{~cm}^{-1} \mathrm{yr}^{-1}$ or less.

Measurements of the thickness of the exfoliation sheets could be made beneath six of the dated colluvial deposits (Table V), providing an average exfoliation rate of $0.091 \pm 0.025 \mathrm{~mm} \mathrm{yr}^{-1}$ using calibrated radiocarbon ages. Notably, at four of the six sites the calculated exfoliation rates are within 25 per cent of the bedrock lowering rates calculated from these deposits, and at most sites the two rates are thus consistent within the estimated measurement uncertainties. At the other two sites (Railroad Creek \# 1 and Sulphur Creek \#1), the calculated exfoliation rates are much higher than the bedrock lowering rates. As discussed above, erroneously high exfoliation rates would be calculated if all exfoliation sheets were not stripped from a hollow prior to deposition of the basal colluvium, possibly accounting for these discrepancies in rates.

\section{DISCUSSION}

Estimates of erosion rates in the Oregon Coast Range obtained by several methods are extremely similar. The average bedrock lowering rate of about $0.07 \mathrm{~mm} \mathrm{yr}^{-1}$ calculated from dated colluvial deposits is consistent with calculated bedrock exfoliation rates from the same sites of about $0.09 \mathrm{~mm} \mathrm{yr}^{-1}$ or less. This agreement supports the interpretation from field observations that erosion rates on the hillslopes are generally limited by the rate that exfoliation sheets can develop, and in addition supports the validity of the calculated bedrock lowering rates. The average residence times of about 5000-6000 yr calculated for colluvium on the side slopes in the studied basins suggests that most of the slope materials are Holocene in age, in turn suggesting an equilibrium with present vegetation and climate. Measurements of stream sediment yield from both undisturbed and disturbed basins provide comparable basin-wide erosion rates of about $0.05-0.08 \mathrm{~mm} \mathrm{yr}^{-1}$, suggesting that there is an approximate balance between late Quaternary hillslope 
sediment production rates and modern stream sediment discharge in this area, although uncertainties inherent in the calculated rates do not allow identification of small differences.

The apparent agreement between hillslope erosion and sediment yield in the Oregon Coast Range contrasts with results from other areas which suggest that hillslope sediment production rates and modern sediment yields are not equal, with the latter depending strongly on storage effects or spatial variations in erosion rates. For example, an inverse relationship between sediment yield and basin area has been proposed by many workers, interpreted as recording such effects as greater erosion rates in headwater basins and progressive downstream storage of sediment (e.g. Brune, 1950; Langbein and Schumm, 1958; Wilson, 1973; Walling, 1983). In some areas, a positive correlation between sediment yield and basin area has been reported, interpreted as recording the downstream erosion of previously stored sediment (e.g. Church and Slaymaker, 1989). In contrast, no systematic relation between sediment yield and drainage area is apparent for Oregon Coast Range basins varying in size by three orders of magnitude (Figure 7). The similarity in sediment yield for basins of varying size suggests that denudation rates in all parts of the basins are similar and supports the interpretation that storage effects along the streams are relatively minor and that sediment yield mainly reflects long-term hillslope erosion rates. This interpretation is consistent with the assumption of equilibrium made by Dietrich and Dunne (1978) in constructing a sediment budget for the Rock Creek drainage basin in coastal Oregon.

Fluctuations in sediment yield over different spatial and temporal scales have undoubtedly occurred in the Oregon Coast Range. Short-term increases in sediment yield occur related to land-use changes, major fires, and major storms (e.g. Brown and Krygier, 1971; Beschta, 1978; Swanson, 1981; Benda, 1990a, 1990b). Longer-term changes in sediment yield may also occur related to regional climatic changes. For example, the clustering of basal radiocarbon dates from the Oregon Coast Range colluvial deposits at $c a .4-7.5$ ka raises the possibility of more frequent landsliding, and therefore larger sediment yield, in the mid-Holocene (Reneau and Dietrich, 1990). Increased discharge of sediment from hillslopes at other periods in the past is also suggested by the occurrence of thick alluvial deposits on terraces, contrasting with the modern streams where little alluvium is in storage. A period of stream aggradation during the Pleistocene-Holocene transition may be recorded by 2-3 m thick alluvial deposits on a $c a$. $10 \mathrm{ka}$ terrace on Drift Creek in the Alsea River basin (Grabau, 1990), and an earlier period of stream aggradation may be recorded by a $7 \mathrm{~m}$ thick alluvial section on a $>42 \mathrm{ka}$ terrace of Sweet Creek in the Siuslaw River basin (Reneau, 1988). The data presented here suggests that, in the context of basin-wide sediment budgets, such fluctuations in sediment yield are not significant at present, although small departures from equilibrium are again not recognizable.

It has been proposed by other workers that the inverse relationship commonly seen between sediment yield and basin area may often reflect temporarily aggrading streams associated with heavily disturbed

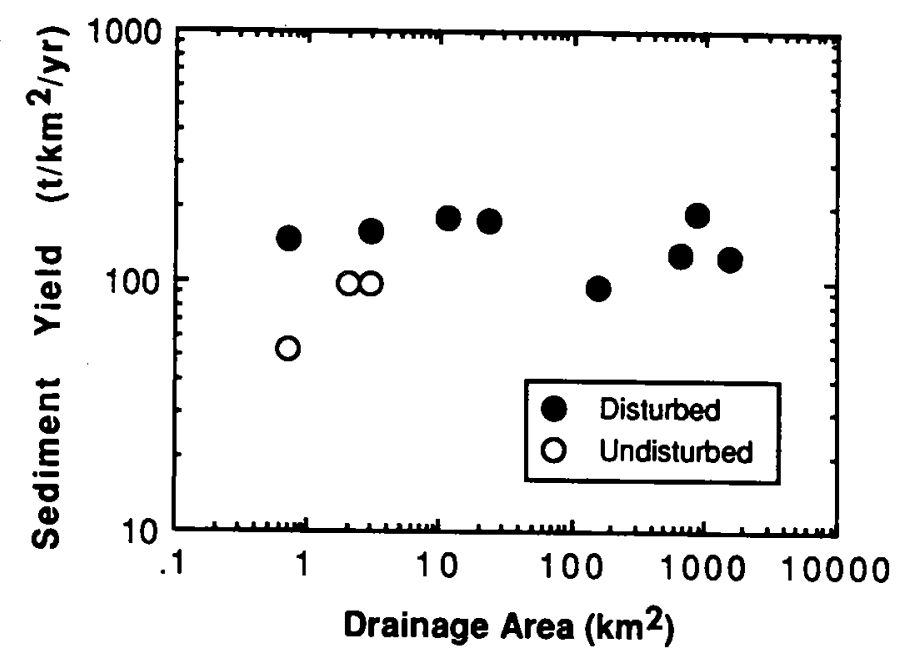

Figure 7. Plot of sediment yield $v$ s. basin area for Oregon Coast Range streams. Data from Table I. 
basins, and not natural landscapes (e.g. Trimble, 1977; Janda and Nolan, 1979; Church and Slaymaker, 1989). Although distinct fill terraces along countless streams provide evidence for naturally aggrading systems, similarly arguing for declining sediment yield with increasing basin area, the periods of aggradation may be characteristic of relatively short periods of time. In addition, the disequilibrium documented by Church and Slaymaker (1989) in British Columbia is strongly related to the storage of large amounts of glacially-derived sediment along rivers in the late Pleistocene, and the subsequent remobilization of this sediment in the Holocene. In contrast, sediment yield in the smaller British Columbia basins, less than $10 \mathrm{~km}^{2}$ in area, may be in equilibrium with bedrock denudation rates (Slaymaker, 1987).

The existence of an approximate equilibrium in the Oregon Coast Range may be associated with an absence of major changes in vegetation or geomorphic processes during the late Quaternary, and with sediment storage sites being relatively small and dispersed. As summarized earlier, the area is unglaciated and may have supported coniferous forests during the late Pleistocene as well as the Holocene. As such, the rivers did not experience major inputs of glacially-derived sediment and slope processes may have changed little during the late Quaternary, limiting the magnitude of fluctuations in sediment storage.

Despite many studies that have argued against the existence of equilibrium conditions on different temporal and spatial scales, each region is unique and the presence of an approximate equilibrium remains a viable initial working hypothesis in a variety of geomorphic contexts. In unglaciated landscapes such as the Oregon Coast Range, long-term hillslope erosion rates may be roughly in balance with bedrock weathering rates (cf. Ahnert, 1987). In the absence of major fluctuations in sediment storage, these may in turn be approximately in balance with stream sediment discharge over large areas. In addition, a similarity in denudation rates in different parts of a basin may suggest a broader 'dynamic equilibrium' in the sense of Hack (1960). An improved understanding of under what conditions and over what temporal and spatial scales landscapes exhibit characteristics of equilibrium or disequilibrium will aid in evaluating short-term landscape change and longer-term landscape evolution.

\section{ACKNOWLEDGMENTS}

The authors thank Walt Shearard of International Paper Company, John Rollins of Champion International Corporation, and Jim Clark of Weyerhaeuser Company for access to study sites; Lee Benda and Fred Swanson for visits to their field sites in the Oregon Coast Range; Preston Jordan and Dave Montgomery for field assistance; and Meyer Rubin of the U.S. Geological Survey and Douglas Donahue and Tim Jull of the University of Arizona for support towards the radiocarbon dating. The manuscript has benefitted from comments by Frank Ahnert, Lee Benda, Chuck Harrington, Ted Oberlander, Parke Snavely, Jr., Fred Swanson, and an anonymous reviewer. Funding in support of this study was provided by National Geographic Societý Grant 3617-87, National Science Foundation Grant EAR-84-51175, a grant from the Pacific Gas and Electric Company, and a Department of Energy postdoctoral fellowship.

\section{REFERENCES}

Adam, D. P., Byrne, R., and Luther, E. 1981a. 'A late Pleistocene and Holocene pollen record from Laguna de las Trancas, northern coastal Santa Cruz County, California', Madroño, 28, 255-272.

Adam, D. P., Sims, J. D., and Throckmorton, C. K. 1981b. '130,000-yr continuous pollen record from Clear Lake, Lake County, California', Geology, 9, 373-377.

Ahnert, F. 1970. 'Functional relationships between denudation, relief, and uplift in large mid-latitude drainage basins', American Journal of Science, 268, 243-263.

Ahnert, F. 1987. 'Approaches to dynamic equilibrium in theoretical simulations of slope development', Earth Surface Processes and Landforms, 12, 3-15.

Badura, G. J., Legard, H. A., and Meyer, L. C. 1974. Siuslaw National Forest Soil Resource Inventory, U.S. Department of Agriculture Forest Service, Siuslaw National Forest, Corvallis, Oregon, $139 \mathrm{pp}$.

Baldwin, E. M. 1974. 'Eocene stratigraphy of southwestern Oregon', Oregon Department of Geology and Mineral Industries Bulletin, 83, $40 \mathrm{pp}$.

Baldwin, E. M. and Beaulieu, J. D. 1973. 'Geology and mineral resources of Coos County, Oregon', Oregon Department of Geology and Mineral Industries Bulletin, 80, 1-40.

Barnosky, C. W. 1985. 'Late Quaternary vegetation near Battle Ground Lake, southern Puget Trough, Washington', Geological Society of America Bulletin, 96, 263-271. 
Benda, L. 1990a. 'Changing patterns of erosion due to land use', EOS (American Geophysical Union Transactions), 71, 1323.

Benda, L. 1990b. 'The influence of debris flows on channels and valley floors in the Oregon Coast Range, U.S.A.', Earth Surface Processes and Landforms, 15, 457-466.

Benda, L. and Dunne, T. 1987. 'Sediment routing by debris flow', in Beschta, R. L., Blinn, T., Grant, G. E., Swanson, F. J., and Ice, G. G. (Eds), Erosion and Sedimentation in the Pacific Rim. International Association of Hydrological Sciences Publication, 165, $213-223$.

Beschta, R. L. 1978. 'Long-term patterns of sediment production following road construction and logging in the Oregon Coast Range', Water Resources Research, 14, 1011-1016.

Brown, G. W. and Krygier, J. T. 1971. 'Clear-cut logging and sediment production in the Oregon Coast Range', Water Resources Research, 7, 1189-1198.

Brune, G. 1950. 'The dynamic concept of sediment sources', Transactions, American Geophysical Union, 31, 587-594.

Carson, M. A. and Kirkby, M. J. 1972. Hillslope Form and Process, Cambridge University Press, Cambridge, 475 pp.

Church, M. and Slaymaker, O. 1989. 'Disequilibrium of Holocene sediment yield in glaciated British Columbia', Nature, 337, $452-454$.

Collins, B. D. and Dunne, T. 1989. 'Gravel transport, gravel harvesting, and channel-bed degradation in rivers draining the southern Olympic Mountains, Washington, U.S.A.', Environmental Geology and Water Sciences, 13, 213-224.

Dethier, D. P. 1986. 'Weathering rates and the chemical flux from catchments in the Pacific Northwest, U.S.A.', in Colman, S. M. and Dethier, D. P. (Eds), Rates of Chemical Weathering of Rocks and Minerals, Academic Press, Orlando, 503-530.

Dietrich, W. E. and Dunne, T. 1978. 'Sediment budget for a small catchment in mountainous terrain', Zeitschrift für Geomorphologie, Supplementband, 29, 191-206.

Franklin, J. F. and Dyrness, C. T. 1973. 'Natural vegetation of Oregon and Washington', U.S. Department of Agriculture Forest Service General Technical Report, PNW-8, 417 pp.

Grabau, P. C. 1990. Floodplain aggradation in an intermontane area of the Oregon Coast Range as a geomorphic response to the Pleistocene-Holocene transition, Unpublished M.S. Thesis, Western Washington University, Bellingham.

Hack, J. T. 1960. 'Interpretation of erosional topography in humid temperate climates', American Journal of Science, 258-A, 80-97.

Hack, J. T. and Goodlett, J. C. 1960. 'Geomorphology and forest ecology of a mountain region in the central Appalachians', U.S. Geological Survey Professional Paper, 347, 66 pp.

Heller, P. L., Peterman, Z. E., O'Neil, J. R., and Shafiquilah, M. 1985. 'Isotopic provenance of sandstones from the Eocene Tyee Formation, Oregon Coast Range', Geological Society of America Bulletin, 96, 770-780.

Heusser, C. J. 1983. 'Vegetational history of the northwestern United States including Alaska', in Porter, S. C. (Ed.), Late-Quaternary Environments of the United States, Volume 1, The Late Pleistocene, University of Minnesota Press, Minneapolis, 239-258.

Heusser, C. J. 1985. 'Quaternary pollen records from the Pacific Northwest coast, Aleutians to the Oregon-California boundary', in Bryant, V. M., Jr. and Holloway, R. G. (Eds), Pollen Records of Late-Quaternary North American Sediments, American Association of Stratigraphic Palynologists, Dallas, 141-165.

Janda, R. J. and Nolan, K. M. 1979. 'Stream sediment discharge in northwestern California', in Guidebook for a Field Trip to Observe Natural and Resource-Management Related Erosion in Franciscan Terrane of Northern California, Geological Society of America, Cordilleran Section, IV-1-27.

Johnson, D. L. 1977. 'The late Quaternary climate of coastal California: evidence for an ice age refugium', Quaternary Research, 8, 154-179.

Karlin, R. 1980. 'Sediment sources and clay mineral distributions off the Oregon coast', Journal of Sedimentary Petrology, 50, 543-560.

Langbein, W. B. and Schumm, S. A. 1958. 'Yield of sediment in relation to mean annual precipitation', Transactions, American Geophysical Union, 39, 1076-1084.

Larsen, K. R. and Sidle, R. C. 1980. Erosion and Sedimentation Data Catalog of the Pacific Northwest, U.S. Department of Agriculture Forest Service Pacific Northwest Region, R6-WM-050-1981, 64 pp.

Pierson, T. C. 1977. Factors controlling debris-flow initiation on forested hillslopes in the Oregon Coast Range, Unpublished Ph.D. Thesis, University of Washington, Seattle, $166 \mathrm{pp}$.

Reneau, S. L. 1988. Depositional and erosional history of hollows: application to landslide location and frequency, long-term erosion rates, and the effects of climatic change, Unpublished Ph.D. Thesis, University of California, Berkeley, $328 \mathrm{pp}$.

Reneau, S. L. and Dietrich, W. E. 1990. 'Depositional history of hollows on steep hillslopes, coastal Oregon and Washington', National Geographic Research, 6, 220-230.

Reneau, S. L., Dietrich, W. E., Rubin, M., Donahue, D. J., and Jull, A. J. T. 1989. 'Analysis of hillslope erosion rates using dated colluvial deposits', Journal of Geology, 97, 45-63.

Schumm, S. A. 1963. 'The disparity between present rates of denudation and orogeny', U.S. Geological Survey Professional Paper, 454-H, $13 \mathrm{pp}$.

Slaymaker, O. 1987. 'Sediment and solute yields in British Columbia and Yukon: their geomorphic significance reexamined', in Gardiner, V. (Ed.), International Geomorphology 1986, Part 1, John Wiley and Sons Ltd., 925-945.

Snavely, P. D., Jr., Wagner, H. C., and MacLoed, N. S. 1964. 'Rhythmic-bedded eugeosynclinal deposits of the Tyee Formation, Oregon Coast Range', Kansas Geological Survey Bulletin, 169, 461-480.

Stuiver, M., Kromer, B., Becker, B., and Ferguson, C. W. 1986. 'Radiocarbon age calibration back to 13,300 years BP and the ${ }^{14} \mathrm{C}$ age matching of the German oak and U.S. bristlecone pine chronologies', Radiocarbon, 28, 969-979.

Stuiver, M. and Reimer, P. J. 1986. 'A computer program for radiocarbon age calibration', Radiocarbon, 28, $1022-1030$.

Swanson, F. J. 1981. 'Fire and geomorphic processes', in Fire Regimes and Ecosystem Properties. U.S. Department of Agriculture Forest Service General Technical Report, WO-26, 401-420.

Swanson, F. J., Swanson, M. M., and Woods, C. 1981. 'Analysis of debris-avalanche erosion in steep forest lands: An example from Mapleton, Oregon, USA', in Davies, T. R. H. and Pearce, A. J. (Eds), Erosion and Sediment Transport in Pacific Rim Steeplands. International Association of Hydrological Sciences Publication, 132, 67-75.

Trimble, S. W. 1977. 'The fallacy of stream equilibrium in contemporary denudation studies', American Journal of Science, $277,876-887$.

Walling, D. E. 1983. 'The sediment delivery problem', Journal of Hydrology, 65, 209-237.

Wilson, L. 1973. 'Variations in mean annual sediment yield as a function of mean annual precipitation', American Journal of Science, 273, 335-349. 